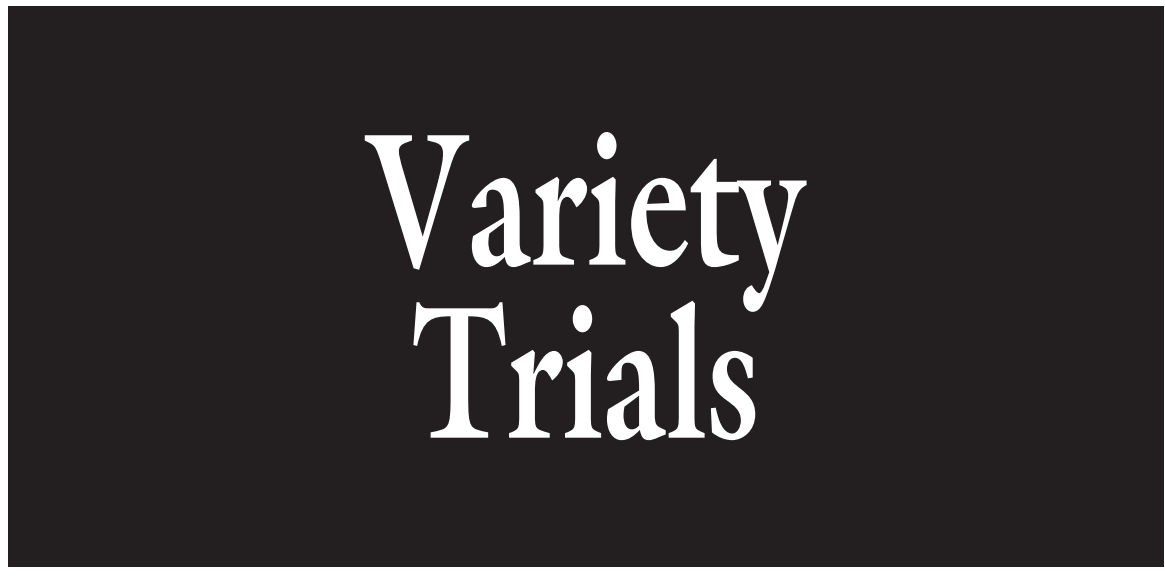

\section{Pennsylvania Statewide Bell Pepper Cultivar Evaluation}

\author{
Elsa S. Sánchez ${ }^{1,8}$, Thomas M. Butzler², Steven M. Bogash ${ }^{3}$, \\ Timothy E. Elkner ${ }^{4}$, R. Eric Oesterling ${ }^{5}$, Michael D. Orzolek ${ }^{6}$, \\ and Lee J. Stivers ${ }^{7}$
}

AdDitional INDEX WORDS. variety trial, Capsicum annuum

Summary. Sixteen cultivars of green bell peppers (Capsicum annuum) were evaluated on the basis of yield in three locations across Pennsylvania during the growing seasons of 2008-09. Cultivars were evaluated in comparison with the cultivar Paladin. In central Pennsylvania, all the cultivars trialed had marketable yields (based on weight) not different than 'Paladin' except 'Lynx', 'Socrates', and 'Escape'. In terms of fruit number, all cultivars were not different than 'Paladin' except 'Socrates'. For large-sized fruit, all the cultivars trialed are recommended. In southeastern Pennsylvania, all the cultivars trialed except SP-05-47 had marketable yields not different than 'Paladin'. For large-sized fruit, 'Revolution' outperformed all other cultivars, including 'Paladin'. In southwestern Pennsylvania, all the cultivars trialed except Lynx and SP-05-47 produced comparable marketable yields to 'Paladin'. None of the cultivars evaluated, including Paladin, consistently outperformed Revolution in terms of large fruit. Statewide, all the cultivars, except Lynx and SP-05-47, are recommended on the basis of marketable yields. For growers looking for large-sized fruit to meet market demand the cultivar Revolution is recommended over 'Paladin'.

$\mathrm{N}$ umerous options are available when selecting cultivars. It is not uncommon for a cultivar to perform well in one region or state and poorly in another. This can make selection time-consuming and leave growers unsure about how new cultivars will perform on their farms. To provide growers in Pennsylvania with regionally appropriate and statewide recommendations, a 10-year-coordinated cultivar evaluation program was started in 2008 with funding from the Pennsylvania Vegetable Research and Marketing Board.

Green bell peppers were the first crop evaluated. They were selected through a survey of growers attending the 2006 Western Pennsylvania
Vegetable and Berry Growers Seminar as being the number one crop on which they wanted research to be conducted. Bell peppers are an important crop for Pennsylvania. In fact, PA has the largest number of bell pepper growers in the United States with 1038 of 4338 vegetable growers producing them [U.S. Department of Agriculture (USDA), 2009]. They are often grown on diversified vegetable farms and sold in the fresh market (USDA, 2009). In 2008-09, 16 cultivars, including one standard, 'Paladin', were evaluated in the field and judged on yield characteristics.

Evaluations were conducted in three locations: southwestern, central, and southeastern Pennsylvania. Locations were selected to represent varying environmental conditions across the state. Results from individual locations were used in establishing regionally appropriate recommendations. This approach also allowed development of statewide recommendations by determining which cultivars performed well across the evaluation sites. These cultivars can be considered widely adaptable as they exhibited consistently favorable yields when grown in the varying environments encountered at each site over the 2-year evaluation period and with diverse cultural methods employed at each location.

\section{Materials and methods}

To capture the varying environmental conditions across the state, the evaluation sites were located in central Pennsylvania at the Russell E. Larson Research and Education Center, Rock Springs (lat. $40^{\circ} 42^{\prime} 45.04 " \mathrm{~N}$, long. $\left.77^{\circ} 57^{\prime} 12.44^{\prime \prime} \mathrm{W}\right)$, in southeastern Pennsylvania at the Southeast Agricultural Research and Extension Center, in Manheim (lat. $40^{\circ} 07^{\prime} 05.11$ ”N, long. $76^{\circ} 25^{\prime} 45.69$ 'W), and in southwestern Pennsylvania at two grower's fields-Janoski Farms in Clinton (lat. $40^{\circ} 29^{\prime} 38.18^{\prime \prime} \mathrm{N}$, long. $80^{\circ} 18^{\prime} 40.88^{\prime \prime} \mathrm{W}$ ) in 2008 and Triple B Farms in Monongahela (lat. $40^{\circ} 13^{\prime} 41.42^{\prime} \mathrm{N}$, long. $79^{\circ} 56^{\prime} 42.66^{\prime \prime} \mathrm{W}$ ) in 2009 (Fig. 1).

Cultivars evaluated were selected on the basis of their potential to produce higher yields than the standard cultivar Paladin (Table 1). 'Paladin' has been the only cultivar listed yearly as a recommended cultivar in the Commercial Vegetable Production Recommendations guide since 2001 (Orzolek et al., 2001). Additionally, it has resistance to phytophthora root rot, an

\begin{tabular}{llll}
\hline $\begin{array}{l}\text { Units } \\
\text { To convert U.S. to SI, } \\
\text { multiply by }\end{array}$ & U.S. unit & SI unit & $\begin{array}{l}\text { To convert SI to U.S., } \\
\text { multiply by }\end{array}$ \\
\hline 0.3048 & $\mathrm{ft}$ & $\mathrm{m}$ & 3.2808 \\
2.54 & inch(es) & $\mathrm{cm}$ & 0.3937 \\
0.4536 & $\mathrm{lb}$ & $\mathrm{kg}$ & 2.2046 \\
1.1209 & $\mathrm{lb} / \mathrm{acre}$ & $\mathrm{kg} \cdot \mathrm{ha}^{-1}$ & 0.8922 \\
0.0254 & mil & $\mathrm{mm}$ & 39.3701
\end{tabular}


important disease in pepper production. All the cultivars evaluated were blocky in shape and harvested green.

The cultivars were arranged in a randomized complete block design with four replications and 20 plants per cultivar in a block. Black embossed plastic mulch (1 mil; Sigma Plastics Group, Allentown, PA) with drip tape (T-Tape model 508-12-450; John Deere, Moline, IL) centered on 3$\mathrm{ft}$-wide and 6-inch-high raised beds, was applied before transplanting at all locations. Pests were managed in accordance with recommendations for commercial production of green bell peppers (Orzolek et al., 2008).

At the central Pennsylvania site, field planting of $\approx 10$ - or 6 -week-old transplants occurred on 13 June 2008 and 20 May 2009, respectively. Plants were spaced 12 inches apart in a single row staggered to the drip line on beds on 7 -ft centers. Harvest began on 25 July 2008 and 7 Aug. 2009 and ended on 29 Sept. 2008 and 14 Sept. 2009. The soil was a Hagerstown silt loam. Adhering to commercial recommendations for Pennsylvania, nitrogen $(\mathrm{N})$ was applied both years at a rate of 75 lb/acre N (Orzolek et al., 2008). Sixty percent was applied preplant as urea and $40 \%$ was applied via fertigation in five weekly applications using $20 \mathrm{~N}-$ 4.4P-16.6K (Peat-Lite Special; Olympic Horticultural Products, Mainland,

\footnotetext{
We acknowledge the Pennsylvania Vegetable Research and Marketing Board for funding this project. We thank the on-farm collaborators at Janoski Farms and Triple B Farms as well as Seedway LLC, Abbott \& Cobb, and NeSeed.com for their generous donation of seeds used in this study and also our families for their support.
}

Use of trade names does not imply endorsement of the products named or criticism of similar products not named.

${ }^{1}$ Associate Professor, Department of Horticulture, The Pennsylvania State University, University Park, PA 16802

${ }^{2}$ Extension Educator, Penn State Cooperative Extension, 47 Cooperation Lane, Mill Hall, PA 17751

${ }^{3}$ Associate Extension Educator, Penn State Cooperative Extension, 181 Franklin Farms Lane, Chambersburg, PA 17202

${ }^{4}$ Senior Extension Educator, Penn State Cooperative Extension, 1383 Arcadia Road, Room 140, Lancaster, PA 17601

${ }^{5}$ Associate Extension Educator, Penn State Cooperative Extension, 214 Donohoe Road, Suite E, Greensburg, PA 15601

${ }^{6}$ Professor, Department of Horticulture, The Pennsylvania State University, University Park, PA 16802

${ }^{7}$ Senior Extension Educator, Penn State Cooperative Extension, 100 West Beau Street, Suite 601, Washington, PA 15301

${ }^{8}$ Corresponding author. E-mail: esanchez@psu.edu.
PA). Preseason soil analysis revealed phosphorus $(\mathrm{P})$ and potassium $(\mathrm{K})$ soil levels to be within optimum ranges in both years.

At the southeastern Pennsylvania site, field planting of $\approx 7$-week-old transplants occurred on 3 June 2008 and 2009. Plants were arranged in a double row with 18 -inch spacing between plants in a row and between rows. Beds were spaced on 10 -ft centers. Plants were staked both years using a modified Florida weave system. Harvest began on 29 July 2008 and 3 Aug. 2009 and ended on 14 Oct. 2008 and 1 Oct. 2009. The soil was a Hagerstown silt loam. Nitrogen was applied both years at a rate of $75 \mathrm{lb} /$ acre N (Orzolek et al., 2008) through weekly fertigation events beginning 2 weeks after transplanting. Phosphorus and $\mathrm{K}$ were applied throughout the season based on tissue test results.

In southwestern Pennsylvania $\approx 8$-week-old transplants were placed in the field on 2 June 2008 and 1 June 2009. The first harvest occurred on 31 July 2008 and 3 Aug. 2009 and the last harvest was on 1 Oct. 2008 and 17 Sept. 2009.

Cultural practices varied in each year of the evaluation in southwestern Pennsylvania. In the 2008 planting at Janoski's Farm, plants were placed in single, nonstaked rows with 12 -inch spacing between plants. Beds were on 5 -ft centers. In addition, $700 \mathrm{lb} /$ acre of $19 \mathrm{~N}-8.3 \mathrm{P}-15.8 \mathrm{~K}$ were added preplant to supply $133 \mathrm{lb} /$ acre $\mathrm{N}$ to the Dormant silt loam.

The 2009 planting system at Triple B Farms used a double row with plants staggered on each side of the drip line with 12 -inch spacing in each row of the pair. Beds were on 5 -ft centers. Plants were staked with a modified Florida weave system. The field consisted of a Guernsey silt loam. Soil analysis revealed $\mathrm{pH}, \mathrm{P}$, and $\mathrm{K}$ soil levels to be below the optimum range. Adhering to recommendations, $150 \mathrm{lb} /$ acre $\mathrm{P}$ and $150 \mathrm{lb} /$ acre $\mathrm{K}$ were broadcast preplant, along with pelleted lime at $200 \mathrm{lb} /$ acre before rototilling and laying plastic. Nitrogen was applied at a rate of $150 \mathrm{lb} /$ acre with $58 \%$ applied preplant as urea and $42 \%$ applied via fertigation in weekly applications.

Fruit were harvested every 10-14 d as they reached maturity with data collected from 10 plants. Fruit was categorized as marketable or unmarketable, counted, and weighed. Marketable fruit were graded by size: 4 -inches diameter or greater was categorized as large, 3 - to 4 -inches diameter as medium, and $<3$ inches diameter as small. Unmarketable fruit were blemished or misshapen.

Data were analyzed with General Linear Model Analysis of Variance using SAS (version 9.1.3; SAS Institute, Cary, NC). When significant effects at $P \leq 0.05$ were detected, Duncan's least significant difference test was used to separate cultivar means. Data from each site were analyzed separately, to account for different cultural methods used at each site.

\section{Results and discussion}

Central Pennsylvania. In 2008 , the number of marketable fruit produced was not different between cultivars (Table 2). In 2009, the cultivars Summer Sweet no. 209, Excursion II, Karisma, Revolution, and Lantern produced more fruit than the standard cultivar Paladin, whereas cultivar Socrates produced fewer fruit.

In 2008, yields by weight from 'Lynx' were less than from 'Paladin'. In 2009, the cultivars Summer Sweet no. 209, Excursion II, Karisma, and Revolution yields by weight were greater than from cultivar Paladin, whereas cultivars Escape, Lynx, and Socrates were lower.

In both years, all cultivars produced a similar number of large fruit to 'Paladin' (Table 2). In 2008, no differences were observed in the weight of large fruit compared with 'Paladin'. Differences were observed in 2009 where the weight of large fruit from 'Karisma' and 'Revolution' was greater than from 'Paladin'.

Very few peppers were unmarketable (Table 2). Differences in unmarketable yields between cultivars were not detected in either year of the evaluation.

Numerically, marketable and large yields in 2008 were lower compared with 2009. Spring 2008 was wet due to rain events that delayed planting until transplants were 10-weeks old, whereas, in 2009 6-week-old transplants were field planted. However, researchers have found that compared with 8-week-old transplants, planting 11-week-old transplants resulted in a higher number of fruit produced or did not affect yield (McCraw and Grieg, 1986). Early in the 2008 season, issues with the irrigation system were encountered, which resulted in water stress to the 


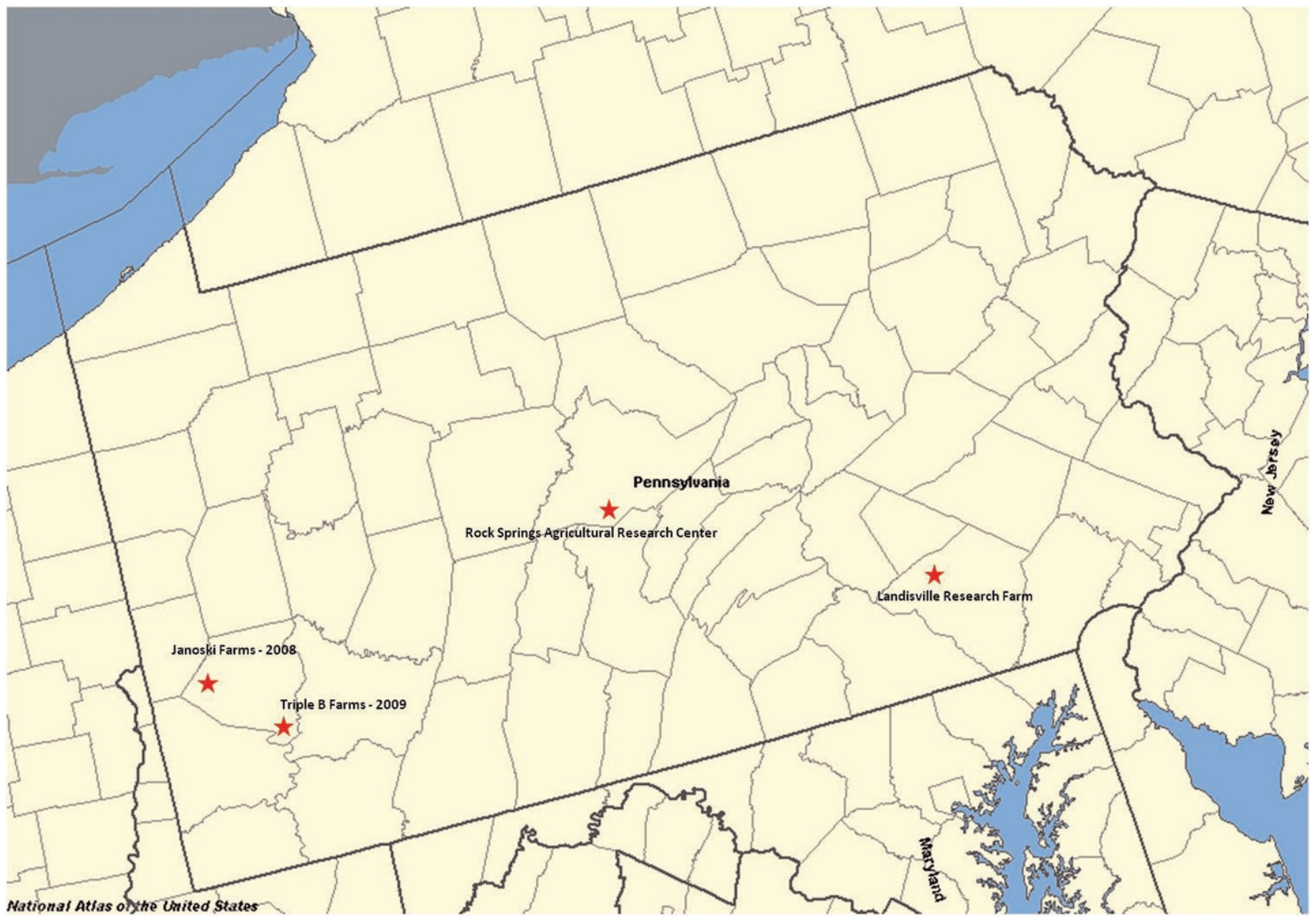

Fig. 1. Bell pepper cultivar evaluation sites in southwestern, central, and southeastern Pennsylvania in $2008-09$.

Table 1. Cultivars and seed sources of green bell peppers grown in central, southeastern, and southwestern Pennsylvania in 2008-09.

\begin{tabular}{lll}
\hline Yr tested & \multicolumn{1}{c}{ Cultivar } & \multicolumn{1}{c}{ Seed company } \\
\hline 2008,2009 & Lantern & Enza Zaden (Salinas, CA) \\
2008,2009 & Paladin & Rogers/Syngenta Seeds (Boise, ID) \\
2008,2009 & Revolution & Harris Moran Seed (Modesto, CA) \\
2008,2009 & Aristotle & Seminis Vegetable Seeds (St. Louis, MO) \\
2008,2009 & Snapper & Enza Zaden \\
2008,2009 & Red Bull & Sakata Seed America (Morgan Hill, CA) \\
2008,2009 & Socrates & Seminis Vegetable Seeds \\
2008,2009 & Summer Sweet & Abbott \& Cobb (Feasterville, PA) \\
& no. 209 & \\
2008,2009 & ACR 285 & Abbott \& Cobb \\
2008,2009 & Escalade & Abbott \& Cobb \\
2008,2009 & Early Excursion & Abbott \& Cobb \\
2008,2009 & Excursion II & Abbott \& Cobb \\
2008,2009 & Escape & Abbott \& Cobb \\
2008,2009 & Polaris & Western Seed (Naaldwijk, The \\
& & Netherlands) \\
2008,2009 & Lynx & DP Seeds (Yuma, AZ) \\
2008,2009 & SP-05-47 & DP Seeds \\
2008 & Legionnaire & Rogers/Syngenta Seeds \\
2008 & Stiletto & Rogers/Syngenta Seeds \\
2009 & Karisma & Harris Moran Seed \\
2009 & PS1819 & Seminis Vegetable Seeds \\
2009 & Intruder & Rogers/Syngenta Seeds \\
\hline & &
\end{tabular}

plants which could explain the differences in yields between 2008 and 2009.

For growers marketing bell peppers on the basis of weight, all trialed cultivars except 'Lynx', 'Socrates', and 'Escape' are recommended. For those marketing based on number, all cultivars except Socrates are recommended. All evaluated cultivars are recommended for those interested in large-sized fruit. The cultivars Legionnaire, Stiletto, Karisma, PS1819, and Intruder showed potential; however, as they were only evaluated 1 year, definitive conclusions cannot be drawn.

Southeastern Pennsylvania. In 2008, no differences were detected between 'Paladin' and the other entries in terms of number or weight of marketable fruit (Table 3). In 2009, 'Early Excursion' produced a larger number and greater weight of marketable fruit than 'Paladin', whereas 'SP-05-47' produced fewer fruit, which resulted in significantly less marketable weight.

Revolution was the only cultivar that yielded more large fruit in terms of 
Table 2. Number and weight of marketable, large [ $>4$-inches $(10.2 \mathrm{~cm})$ diameter], and unmarketable fruit of several cultivars of green bell peppers grown in central Pennsylvania in 2008-09. Values are the means of four replications.

\begin{tabular}{|c|c|c|c|c|c|c|c|c|c|c|}
\hline Cultivar & \multicolumn{2}{|c|}{$\begin{array}{c}\text { Mean } \\
\text { marketable } \\
\text { fruit (no./10 } \\
\text { plants) } \\
\end{array}$} & \multicolumn{2}{|c|}{$\begin{array}{c}\text { Mean } \\
\text { marketable } \\
\text { fruit wt }(1 \mathrm{l} / 10 \\
\text { plants }^{\mathrm{z}}\end{array}$} & \multicolumn{2}{|c|}{$\begin{array}{c}\text { Mean large } \\
\text { fruit (no./10 } \\
\text { plants) }\end{array}$} & \multicolumn{2}{|c|}{$\begin{array}{c}\text { Mean large } \\
\text { fruit wt (lb/10 } \\
\text { plants) }\end{array}$} & $\begin{array}{c}\text { Mean } \\
\text { unmarketable } \\
\text { fruit (no./10 } \\
\text { plants) }\end{array}$ & $\begin{array}{c}\text { Mean } \\
\text { unmarketable } \\
\text { fruit wt (lb/10 } \\
\text { plants) }\end{array}$ \\
\hline Escape & 81.3 & - & 23.4 & $a^{y}$ & 36.5 & - & 13.5 & $\mathrm{a}-\mathrm{e}$ & 4.00 & 0.925 \\
\hline Legionnaire & 79.8 & - & 24.7 & $\mathrm{a}$ & 41.0 & - & 16.2 & $\mathrm{ab}$ & 2.75 & 0.750 \\
\hline Paladin $^{x}$ & 74.8 & - & 20.6 & $a b$ & 36.3 & - & 12.5 & $\mathrm{a}-\mathrm{e}$ & 1.50 & 0.400 \\
\hline Escalade & 71.8 & - & 22.3 & $\mathrm{a}$ & 32.5 & - & 12.3 & $\mathrm{a}-\mathrm{e}$ & 1.25 & 0.300 \\
\hline Aristotle & 70.5 & - & 21.9 & $\mathrm{a}$ & 35.8 & - & 13.4 & $\mathrm{a}-\mathrm{e}$ & 1.25 & 0.450 \\
\hline SP-05-47 & 70.3 & - & 20.5 & $a b$ & 47.8 & - & 14.5 & $\mathrm{a}-\mathrm{d}$ & 1.25 & 0.225 \\
\hline Lantern & 69.8 & - & 20.5 & $\mathrm{ab}$ & 35.0 & - & 12.7 & $\mathrm{a}-\mathrm{e}$ & 4.00 & 0.550 \\
\hline Socrates & 68.3 & - & 19.2 & $a-c$ & 37.0 & - & 12.7 & $\mathrm{a}-\mathrm{e}$ & 2.75 & 0.400 \\
\hline Polaris & 67.0 & - & 23.3 & $\mathrm{a}$ & 37.3 & - & 15.3 & $a-c$ & 2.00 & 0.375 \\
\hline $\begin{array}{l}\text { Summer Sweet } \\
\text { no. } 209\end{array}$ & 48.3 & - & 13.0 & $\mathrm{bc}$ & 21.5 & - & 7.70 & de & 1.00 & 0.150 \\
\hline \multirow[t]{2}{*}{ Lynx } & 42.5 & - & 13.7 & c & 18.8 & - & 7.08 & $\mathrm{e}$ & 2.50 & 0.525 \\
\hline & & & & & \multicolumn{2}{|c|}{2009} & & & & \\
\hline $\begin{array}{l}\text { Summer Sweet } \\
\text { no. } 209\end{array}$ & 123 & $\mathrm{a}$ & 53.8 & $a b$ & 89.5 & $\mathrm{a}$ & 45.8 & $a-c$ & 3.75 & 1.33 \\
\hline Excursion II & 103 & $\mathrm{~b}$ & 52.1 & $\mathrm{a}-\mathrm{d}$ & 85.8 & $a b$ & 46.5 & $a-c$ & 2.50 & 0.725 \\
\hline Karisma & 102 & $\mathrm{~b}$ & 55.5 & $\mathrm{a}$ & 88.6 & a & 52.0 & a & 3.00 & 1.03 \\
\hline Revolution & 100 & $\mathrm{bc}$ & 52.8 & $a-c$ & 86.5 & $\mathrm{a}$ & 48.0 & $\mathrm{ab}$ & 5.25 & 1.63 \\
\hline Lantern & 100 & $\mathrm{bc}$ & 44.8 & $c-f$ & 90.3 & $\mathrm{a}$ & 41.6 & $\mathrm{a}-\mathrm{d}$ & 3.75 & 1.33 \\
\hline Aristotle & 85.8 & $b-g$ & 47.2 & $\mathrm{~b}-\mathrm{e}$ & 70.0 & $b-d$ & 37.9 & $b-f$ & 4.00 & 1.10 \\
\hline PS1819 & 82.8 & $\mathrm{c}-\mathrm{g}$ & 44.0 & $d-f$ & 76.8 & $a-c$ & 42.2 & $\mathrm{a}-\mathrm{d}$ & 4.00 & 1.28 \\
\hline Paladin & 80.8 & $\mathrm{~d}-\mathrm{g}$ & 43.2 & ef & 73.0 & $\mathrm{a}-\mathrm{d}$ & 36.8 & $c-f$ & 3.75 & 1.08 \\
\hline Polaris & 76.0 & $\mathrm{e}-\mathrm{h}$ & 40.9 & $\mathrm{e}-\mathrm{g}$ & 63.8 & $\mathrm{~cd}$ & 38.0 & $b-f$ & 2.00 & 0.550 \\
\hline Intruder & 74.3 & $\mathrm{f}-\mathrm{h}$ & 37.8 & $\mathrm{fg}$ & 65.0 & $b-d$ & 35.9 & $c-f$ & 3.50 & 0.725 \\
\hline Escape & 68.8 & gh & 34.6 & gh & 55.0 & d & 30.4 & ef & 3.25 & 0.950 \\
\hline Lynx & 67.5 & gh & 33.8 & gh & 63.5 & $\mathrm{~cd}$ & 31.0 & $\mathrm{~d}-\mathrm{f}$ & 5.50 & 1.28 \\
\hline Socrates & 58.3 & $\mathrm{~h}$ & 29.3 & $\mathrm{~h}$ & 54.3 & $\mathrm{~d}$ & 28.5 & $\mathrm{f}$ & 3.75 & 0.875 \\
\hline
\end{tabular}

${ }^{\mathrm{z}} \mathrm{l} \mathrm{lb}=0.4536 \mathrm{~kg}$.

'Values followed by different letters within a column are significantly different using Duncan's least significant difference test at the $5 \%$ level.

x $S$ tandard cultivar to which all other means are compared.

number and weight than 'Paladin' in 2008 (Table 3). The cultivars Stiletto, Red Bull, ACR 285, Lynx, Escalade, Lantern, Aristotle, and SP-05-47 produced fewer large-sized fruit than 'Paladin'. By weight, the cultivars Stiletto, ACR 285, Lynx, Escalade, Lantern, Aristotle, and SP-05-47 yields were less than from 'Paladin'. In 2009, 'Revolution' produced more large fruit in terms of number and weight than 'Paladin'.
The majority of unmarketable fruit were as a result of them being misshapen. In 2008 'SP-05-47' and 'Escalade' produced a higher number of unmarketable fruit than 'Paladin' (Table 3 ). In terms of weight, the cultivars SP-05-47, Escalade, and Snapper produced more unmarketable fruit than 'Paladin'. Differences in unmarketable yield were not observed in 2009.
On the basis of marketable weight and number all cultivars, except SP05-47 are recommended. 'Revolution' produced higher yields of large-sized fruit than 'Paladin'. The remaining cultivars produced yields of large-sized fruit that were comparable or lower than 'Paladin'. The cultivars Stiletto, Legionnaire, Karisma, Intruder, and PS1819 showed potential based on marketable yields; however, as they were only 
Table 3. Number and weight of marketable, large [ $>4$-inches $(10.2 \mathrm{~cm})$ diameter], and unmarketable fruit of several cultivars of green bell peppers grown in southeastern Pennsylvania in 2008-09. Values are the means of four replications.

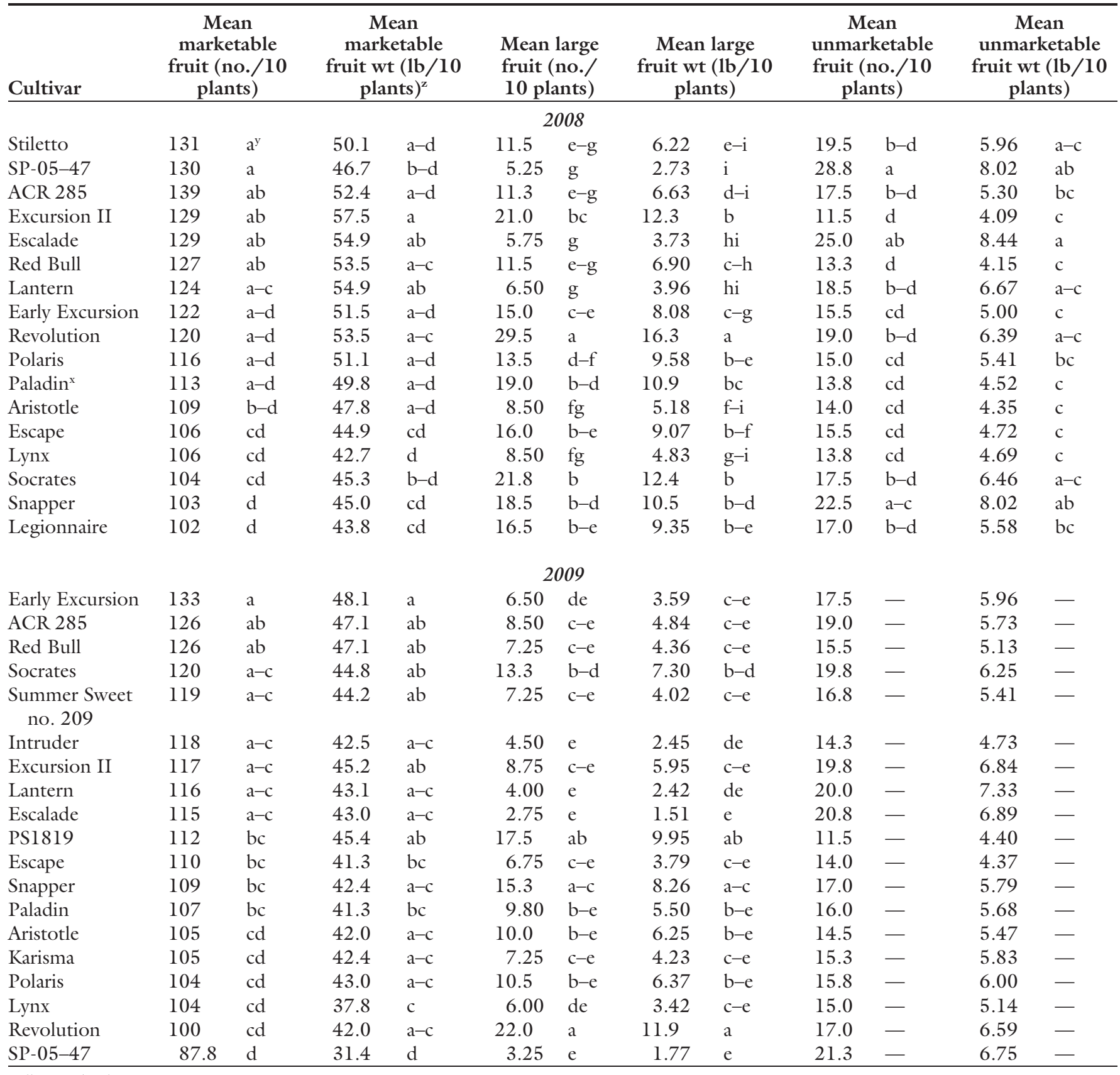

${ }^{\mathrm{z}} \mathrm{l} \mathrm{lb}=0.4536 \mathrm{~kg}$

'Values followed by different letters within a column are significantly different using Duncan's least significant difference test at the $5 \%$ level.

${ }^{x}$ Standard cultivar to which all other means are compared.

evaluated 1 year, definitive conclusions cannot be drawn.

SOUTHWESTERN PENNSYLVANIA. In 2008, significant differences in the number and weight of marketable fruit between cultivars were not detected (Table 4). In 2009, 'Early Excursion' yielded higher than 'Paladin' based on number and weight. 'Lynx' and 'SP-05-47' produced fewer marketable fruit by number and weight than 'Paladin'.
In 2008, more large fruit in terms of number and weight were produced by 'Revolution' and 'Alliance' than 'Paladin.' In 2009, 'Revolution' outperformed 'Paladin' in terms of large fruit number, whereas 'Revolution' and 'Snapper' produced heavier large fruit than 'Paladin'.

Differences in unmarketable yields between cultivars were not detected in 2008 (Table 4). In 2009, 'SP$05-47$ ' produced a larger number of unmarketable fruit than 'Paladin'. 'Snapper' and 'Revolution' by weight had more unmarketable fruit than 'Paladin'.

Although the weight of marketable fruit was numerically similar in both years of the study, there was a trend where the number of marketable fruit was less in 2009 compared with 2008. Each grower cooperator used their standard cultural practices that differed in plant spacing, the use of 
Table 4. Number and weight of marketable, large [ $>4$-inches $(10.2 \mathrm{~cm})$ diameter], and unmarketable fruit of several cultivars of green bell peppers grown in southwestern Pennsylvania in 2008-09. Values are the means of four replications.

\begin{tabular}{|c|c|c|c|c|c|c|c|c|c|c|c|c|}
\hline Cultivar & \multicolumn{2}{|c|}{$\begin{array}{c}\text { Mean } \\
\text { marketable } \\
\text { fruit (no./10 } \\
\text { plants) } \\
\end{array}$} & \multicolumn{2}{|c|}{$\begin{array}{c}\text { Mean } \\
\text { marketable } \\
\text { fruit wt (lb/10 } \\
\text { plants })^{\mathrm{z}} \\
\end{array}$} & \multicolumn{2}{|c|}{$\begin{array}{c}\text { Mean large } \\
\text { fruit (no./10 } \\
\text { plants) }\end{array}$} & \multicolumn{2}{|c|}{$\begin{array}{c}\text { Mean large } \\
\text { fruit wt (lb/10 } \\
\text { plants) }\end{array}$} & \multicolumn{2}{|c|}{$\begin{array}{c}\text { Mean } \\
\text { unmarketable } \\
\text { fruit (no./10 } \\
\text { plants) }\end{array}$} & \multicolumn{2}{|c|}{$\begin{array}{c}\text { Mean } \\
\text { unmarketable } \\
\text { fruit wt (lb/10 } \\
\text { plants) }\end{array}$} \\
\hline Red Bull & 147 & - & 49.8 & - & 4.33 & $b^{y}$ & 2.31 & $\mathrm{~b}$ & 17.8 & - & 6.50 & - \\
\hline $\begin{array}{l}\text { Summer Sweet } \\
\text { no. } 209\end{array}$ & 146 & - & 40.6 & - & 3.07 & $\mathrm{~b}$ & 1.68 & $\mathrm{~b}$ & 15.2 & - & 5.14 & - \\
\hline Early Excursion & 144 & - & 46.5 & - & 5.05 & $\mathrm{~b}$ & 1.79 & $\mathrm{~b}$ & 16.6 & - & 6.55 & - \\
\hline Excursion II & 136 & - & 47.6 & - & 3.06 & $\mathrm{~b}$ & 1.30 & $\mathrm{~b}$ & 11.4 & - & 4.12 & - \\
\hline Alliance $^{\mathrm{x}}$ & 135 & - & 43.6 & - & 19.4 & a & 9.73 & $\mathrm{a}$ & 16.7 & - & 6.80 & - \\
\hline Revolution & 134 & - & 44.5 & - & 27.4 & a & 12.1 & $\mathrm{a}$ & 17.5 & - & 6.66 & - \\
\hline Lantern & 125 & - & 38.2 & - & 3.33 & $\mathrm{~b}$ & 1.54 & $\mathrm{~b}$ & 11.3 & - & 4.03 & - \\
\hline Escape & 125 & - & 40.0 & - & 4.11 & $\mathrm{~b}$ & 1.73 & $\mathrm{~b}$ & 11.9 & - & 4.35 & - \\
\hline Lynx & 109 & - & 37.0 & - & 2.25 & $\mathrm{~b}$ & 1.39 & $\mathrm{~b}$ & 16.1 & - & 5.90 & - \\
\hline Polaris & 108 & - & 39.1 & - & 10.3 & $\mathrm{~b}$ & 5.42 & $\mathrm{~b}$ & 20.6 & - & 8.20 & - \\
\hline Paladin $^{w}$ & 105 & - & 29.3 & - & 4.92 & $\mathrm{~b}$ & 1.96 & $\mathrm{~b}$ & 16.4 & - & 6.06 & - \\
\hline & & & & & 20 & & & & & & & \\
\hline Early Excursion & 94.2 & $\mathrm{a}$ & 43.7 & $\mathrm{a}$ & 7.75 & $b-e$ & 4.73 & $b-f$ & 12.5 & $\mathrm{e}$ & 5.60 & $\mathrm{c}$ \\
\hline Escalade & 84.3 & $\mathrm{ab}$ & 37.7 & $a-c$ & 0.0500 & $\mathrm{e}$ & 0.675 & f & 23.5 & $\mathrm{a}-\mathrm{d}$ & 9.18 & $a-c$ \\
\hline Excursion II & 82.0 & $\mathrm{a}-\mathrm{c}$ & 39.5 & $a b$ & 9.00 & $b-d$ & 5.77 & $b-e$ & 14.7 & $\mathrm{de}$ & 7.27 & $\mathrm{bc}$ \\
\hline ACR 285 & 79.8 & $a-c$ & 37.5 & $a-c$ & 6.00 & $\mathrm{c}-\mathrm{e}$ & 3.98 & $c-f$ & 16.8 & $\mathrm{c}-\mathrm{e}$ & 7.20 & $\mathrm{bc}$ \\
\hline PS1819 & 77.3 & $\mathrm{bc}$ & 38.2 & $a-c$ & 14.0 & $\mathrm{~b}$ & 8.53 & $a-c$ & 18.0 & $\mathrm{~b}-\mathrm{e}$ & 8.47 & $a-c$ \\
\hline Paladin & 77.0 & $\mathrm{bc}$ & 35.3 & $b-d$ & 7.50 & $b-c$ & 3.95 & $c-f$ & 18.3 & $b-c$ & 7.78 & $\mathrm{bc}$ \\
\hline Escape & 66.3 & $\mathrm{c}-\mathrm{e}$ & 32.5 & $\mathrm{c}-\mathrm{e}$ & 10.0 & $b-d$ & 5.93 & $\mathrm{~b}-\mathrm{e}$ & 14.3 & $\mathrm{de}$ & 6.80 & $\mathrm{c}$ \\
\hline Aristotle & 65.8 & $\mathrm{c}-\mathrm{e}$ & 34.5 & $b-d$ & 10.0 & $b-d$ & 6.45 & $b-d$ & 19.3 & $b-c$ & 8.48 & $a-c$ \\
\hline Lynx & 58.0 & de & 26.8 & ef & 2.67 & de & 1.87 & $d-f$ & 14.0 & de & 5.83 & c \\
\hline SP-05-47 & 52.8 & $\mathrm{e}$ & 22.0 & $\mathrm{f}$ & 1.50 & $\mathrm{e}$ & 0.850 & f & 32.5 & $\mathrm{a}$ & 11.4 & $\mathrm{ab}$ \\
\hline
\end{tabular}

${ }^{\mathrm{z}} \mathrm{l} \mathrm{lb}=0.4536 \mathrm{~kg}$.

'Values followed by different letters within a column are significantly different using Duncan's least significant difference test at the $5 \%$ level.

“Alliance' was evaluated only at this location.

wStandard cultivar to which all other means are compared.

staking, and the rate of fertilizer applied. Discrepancies in the number of marketable fruit are likely a function of these differences. For example in 2008, a single row with 12 inches between plants was used, whereas in 2009 a double row with 12 -inch spacing between plants in a row was used. Several studies have found the spatial arrangement of pepper plants to affect yield (Decoteau and Graham, 1994; Kahn and Leskovar, 2006; Locascio and Stall, 1994).

All cultivars, except Lynx and SP05-47, are recommended in terms of marketable yield. 'Revolution' produced higher yields of large-sized fruit than 'Paladin'. The remaining cultivars produced yields of large-sized fruit that were comparable to 'Paladin'. 'PS1819' and 'Intruder' showed potential in terms of marketable yields and 'Alliance' in terms of large yields; however, as they were only evaluated 1 year, definitive conclusions cannot be drawn.

STATEWIdE RECOMMENDATIONS. 'Paladin' has been recommended in Pennsylvania for the past 10 years because of good yielding characteristics and phytophthora resistance. In determining whether a cultivar was suited for statewide recommendation, the criterion was that it must have produced comparable yields to 'Paladin' in a minimum of two of the evaluation sites. Several seed companies have introduced a number of new cultivars the past few years, many of those evaluated in this study preformed equally or better than 'Paladin' in terms of marketable yields. However, the cultivars Lynx and SP05-47 produced lower yields to the current standard and, therefore, are not 
recommended. For growers looking for large-sized fruit to meet market demand the cultivar Revolution is recommended over Paladin. Although conclusions about the cultivars PS1819, Intruder, Karisma, Stiletto, and Legionnaire could not be drawn for each trial location because they were only observed in 1 year of the study, comparing all three sites revealed that they performed well and warrant further evaluation.

Phytophthora crown, root rot, and aerial blight caused by Phytophthora capsici can be a devastating disease of peppers and the use of resistant and/or tolerant cultivars is an important ecologically based management strategy (Ristaino and Johnston, 1999). The cultivars Escalade, Paladin, Revolution, and Alliance are described as having tolerance. The southwestern site experienced phytophthora root rot in 2009; however, because the incidence was minimal, $P$. capsici tolerance was not evaluated.

The pepper cultivars recommended as a result of this study are believed to be suitable for commercial production under conditions common to the mid-Atlantic region. This is based on the performance of tested cultivars over a wide geographic area, two distinctive years, and different cultural practices. The ultimate value of a cultivar is determined by market. Cultivars recommended by the statewide trials can serve as a starting point, recognizing that performances can vary under sitespecific conditions.

\section{Literature cited}

Decoteau, D.R. and H.A. Hatt Graham. 1994. Plant spatial arrangement affects growth, yield, and pod distribution of cayenne peppers. HortScience 29:149-151.

Kahn, B.A. and D.I. Leskovar. 2006. Cultivar and plant arrangement effects on yield and fruit quality of bell pepper. HortScience 41:1565-1570.

Locascio, S.J. and W.M. Stall. 1994. Bell pepper yield as influenced by plant spacing and row arrangement. J. Amer. Soc. Hort. Sci. 119:899-902.
McCraw, B.D. and J.K. Grieg. 1986. Effect of transplant age and pruning procedure on yield and fruit-set of bell pepper. HortScience 21:430-431.

Orzolek, M.D., P.A. Ferretti, W.J. Lamont, Jr., K. Demchak, A.A. MacNab, J.M. Halbrendt, S.J. Fleischer, Z. Smilowitz, and W. Hock. 2001. Commercial vegetable production recommendations. Penn State Coop. Ext. Publ. AGRS-028.

Orzolek, M.D., E. Sánchez, W.J. Lamont, Jr., T. Elkner, K. Demchak, G. Lin, J.M. Halbrendt, S.J. Fleischer, L. LaBorde, K. Hoffman, and G.J. San Julian. 2008. Commercial vegetable production recommendations. Penn State Coop. Ext. Publ. AGRS-028.

Ristaino, J.B. and S.A. Johnston. 1999. Ecologically based approaches to management of phytophthora blight on bell pepper. Plant Dis. 83:1080-1089.

U.S. Department of Agriculture. 2009. 2007 Census of Agriculture, Vol. 1 Chapter 2: State Level Data, Table 30. 13 Aug. 2010. <http://www.agcensus.usda.gov/ Publications/2007/Full_Report/Volume_ 1,_Chapter_2_US_State_Level/st99_2_030_ $030 . p d f>$. 